氡

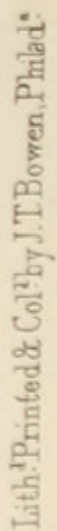

ㄴ.

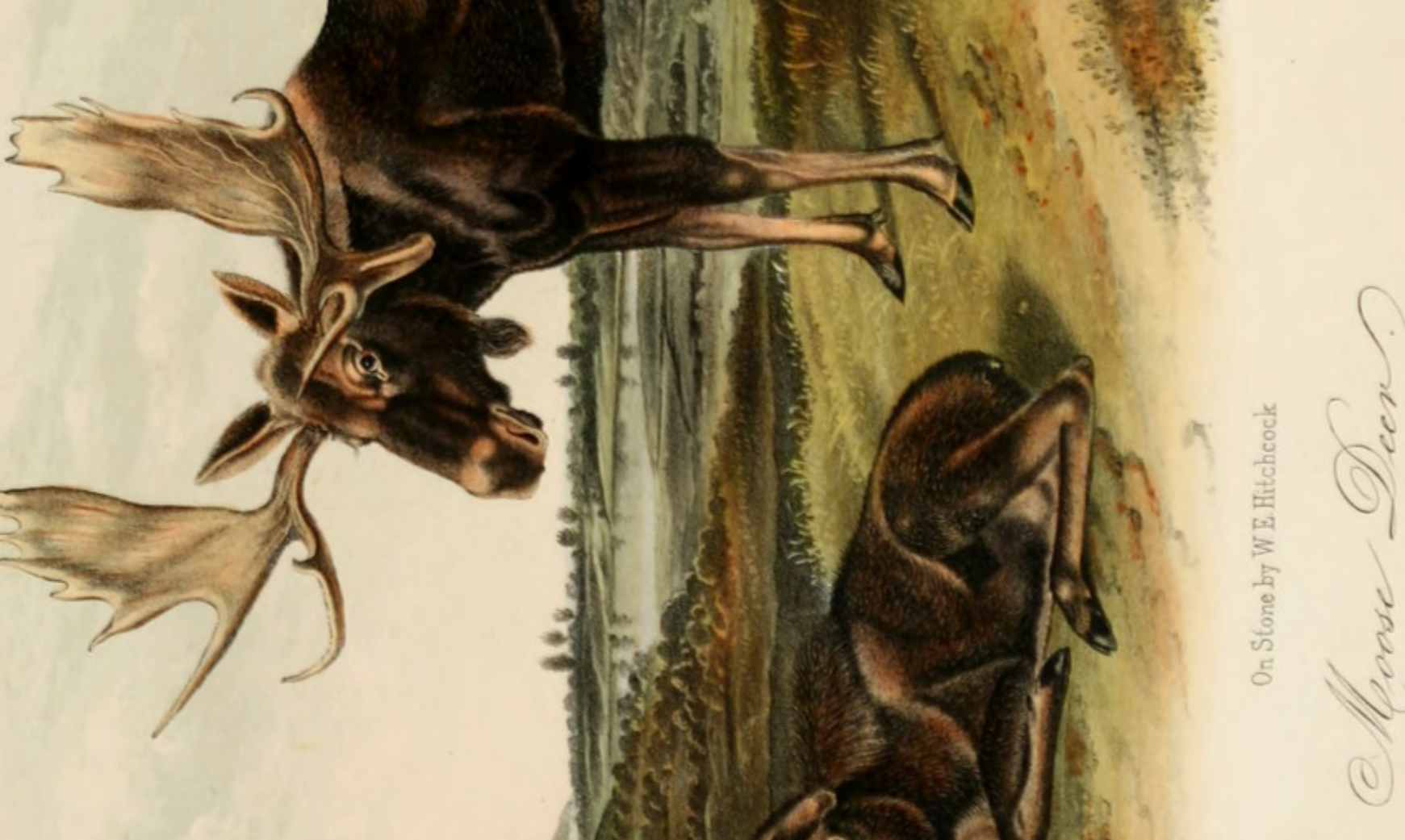





\title{
CERVUS ALCES.-LINN.
}

\author{
Moose Deer.
}

Plate lixXVi. Old Male and Young.

C. magnitudine Equi ; capite permagno, labro auribusque elongatis ; collo brevi, dense jubato, cornibus palmatis, cauda brevissima, vellere fusco cinereo, in nigrum vergente.

\section{CHARACTERS.}

Size of a horse. Head, very large ; snout and ears, long; neck, short, with a thick mane. Horns spreading into a broad palm. Tail, short. Colour, blackish-gray.

\section{SYNONYMES.}

Elan, Stag, or Aptaptov. De Monts Nova Francia, p. 250. An. 1604.

Eslan ou Orinal. Sagard-Theodat, Canada, p. 749. An. 1636.

Orinal. La Hontan, Voy., p. 72. An. 1703.

Moose Deer. Dudley, Phil. Trans. No. 368, p. 165. An. 1721.

Orinal. Charlevoix. Nouv. France. Vol. v., p. 185. An. 1741.

" Dupratz, Louis. Vol. i., p. 301.

Moose Deer. Pennant, Aret. Zool. Vol. i., p. 17, Fig. 1784.

Moose. Umfreville, Huds. Bay. An. 1790.

“ Herriot's Travels, 1807, Fig.

C. Alces. Harlan. Fauna, p. 229.

" Godman, Am. Nat. Hist., Vol. ii., p. 274.

The Elk. Hamilton Smith.

“ Griffith's Cuv., Vol, v., p. 303.

American Black Elk. Griffith's Cuv., Vol. iv., p. 72., plate of head.

Elk. In Nova Scotia, proceedings of the Zoological Society, 1849, p. 93.

Cervus alces. De Kay, N. Hist. N. Y., p. 115.

\section{DESCRIPTION.}

This is the largest of any known species of deer. Major Sмттн (Cuv. An. Kingdom, by Griffiths, Vol. iv., p. 73) says, "For us, who have the opportunity of receiving the animal in all the glory of his full grown horns, 
amid the scenery of his own wilderness, no animal could appear more majestic or more imposing." Having ourselves on one occasion been favoured with a similar opportunity, when we had the gratification of bringing one down with a rifle and of examining him in detail as he lay before us, we confess he appeared awkward in his gait, clumsy and disproportioned in limbs, uncouth and inelegant in form, and possessing less symmetry and beauty than any other species of the deer family. His great size, enormous head, and face like a horse, and the thundering noise of the saplings bending and snapping around him as he rattled over the fallen $\operatorname{logs}$, was to us the only imposing part of the spectacle. To do justice, however, to the description of the moose, by Вмгтн, who was a close observer and a naturalist of considerable attainments, we should quote his succeeding observations: "It is, however, the aggregate of his appearance which produces this effect; for when the proportions of its structure are considered in detail, they certainly will seem destitute of that harmony of parts which in the imagination produces the feeling of beauty."

The head forcibly reminds us of that of an enormous jackass ; it is long narrow and clumsily shaped, by the swelling on the upper part of the nose and nostrils; the snout is long and almost prehensile-the muzzle extending four inches beyond the lower lip. The nostrils are narrow and long, five inches in length. The eye is deep-seated, and in proportion to the large head is small. The ears are long, 14 inches, heavy and asinine. The neck is very short, and is surmounted by a compact mane of moderate length composed of coarse rigid hairs. There is in both sexes a tuft of coarse hairs, resembling hog's bristles, beneath the throat, which is attached to a pendulous gland, more conspicuous in young than in old animals; this gland with the attached hair is ten inches long. The horns, which are found only on the males, are, when a year old, merely short knobs; they increase in size after each annual shedding, and after the fourth year become palmated, and may be termed full grown about the fifth year. The palms on the horns of the Moose are on the widest part on a moderate-sized male about 11 inches wide. The space between the roots, $6 \frac{1}{2}$ inches; greatest breadth at the root, $6 \frac{1}{2}$ inches; from the root to the extremity, measuring around the curve, 2 feet 10 inches. The first branch or prong on the inner side of the horn commences nine inches from the base. It here divides into two branches, one being ten and the other eleven inches in length, measuring in a curve from the root to the largest point 25 inches. These two prongs on each side incline forward, are almost round, and are pointed like those of elk horns. The palms on the main branches of the horns not only differ in different individuals, but do not often correspond on the head of the same animal. In the specimen from which 
we are describing, the lower and longest point on the palm is on one side 12 inches, and on the corresponding one on the opposite side only 4 inches; on the remainder of the palm there are on one side six points, on the other seven; the palm is about half-an-inch in breadth at the centre, thickening towards the base to one inch.

The horns are irregularly and slightly channelled, and are covered with whitish marks on the front surface, somewhat resembling the channels and irregular windings of grubs or sawyers between the bark and wood in old decayed trunks of trees; on the posterior surface these marks in form bear considerable resemblance to veins in the leaves of ferns. The width across the horns measuring from the outer tips rises 3 feet 4 inches; weight of the horns, 42 pounds.

The nose, including the nostrils, is thickly clothed with short hair-a triangular spot on the nose bare. The hair on the mane is coarse and compact, 10 inches in length ; both surfaces of the ears are covered with dense hairs.

The outer hair is throughout coarse and angular; it is longer on the neck and shoulders than on any other part of the body ; under these long hairs there is a shorter, woolly, more dense and finer coat.

\section{COLOUR.}

The teeth are white; horns brownish yellow, the extremities of the prongs becoming yellowish white. The eyes are black; nose, forehead and upper lip, yellowish fawn ; inner surface of ears, yellowish white; outer surface, grayish brown. Sides of head, yellowish brown. On the neck, dark grayish brown, composed of hairs that are white, black and yellow ; under the chin, yellowish brown. Hairs on the appendage under the throat, black; lower lip and chin, dark gray, formed of a mixture of white and black hairs; the softer, shorter hairs on the body are ashy gray; the long hairs when examined separately are whitish at the base, then cinereous and tipped with black, giving it a brownish black appearance.

On the under surface of the body the colour is considerably lighter than on the back, having a tinge of yellowish white; under surface of the tail, ashy white. The young animals, for the first winter, are of a reddish brown colour; individuals even of the same age often differ in colour, some being darker than others, but there is always a striking difference between the summer and winter colours, the hairs in winter becoming darker; as the moose advances in age, the colour continues to deepen until it appears black; thence it was named by Haмmтол Sмiтн, not inappropriately as regards colour, "the American Black Elk" 
DIMENSIONS.

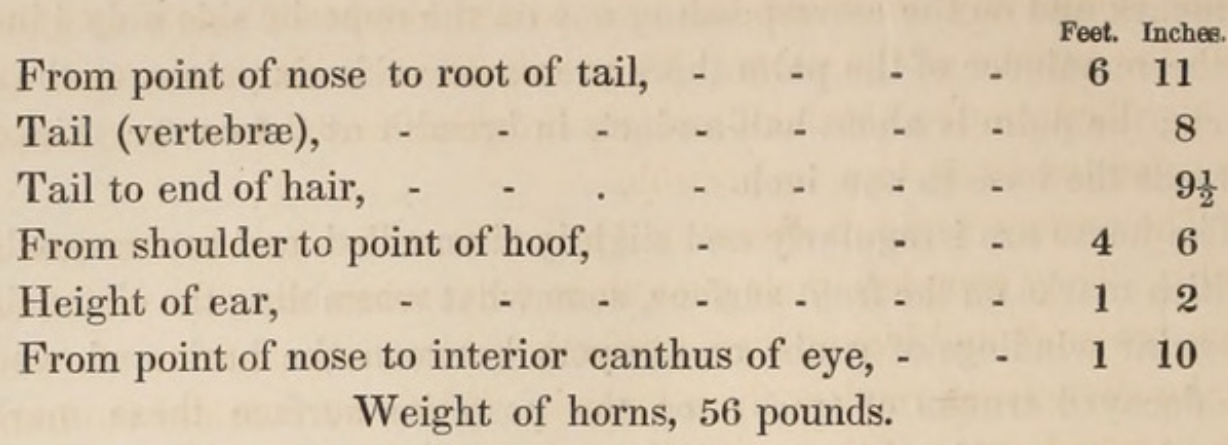

Weight of the whole animal, from 800 to 1200 pounds.

Dimensions of a Male procured in Ontario County, N. Y., in 1806.

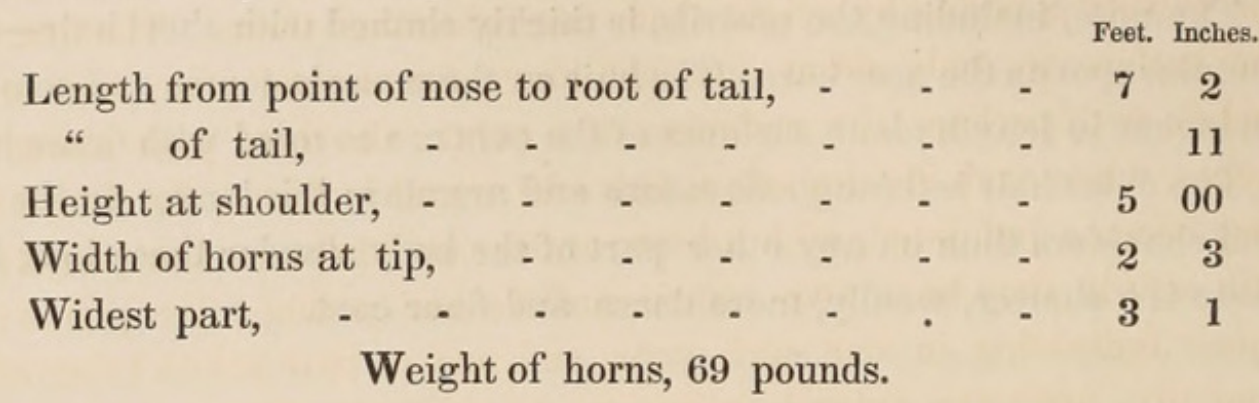

HABITS.

We were favoured by Mr. Kendall, of the Literary Society of Quebec, with the following account of the Moose Deer, with which we will begin our article on this noble quadruped.

"The Moose are abundant to the north of Quebec and in the northern parts of the state of Maine. In the neighbourhood of Moose River and the lakes in its vicinity, they are very abundant. In the summer they are fond of frequenting lakes and rivers, not only to escape the attacks of insects which then molest them, but also to avoid injuring their antlers, which during their growth are very soft and exquisitely sensitive, and besides, such situations afford them abundance of food.

"They there feed on the water-plants, or browse upon the trees fringing the shores. In the winter they retire to the dry mountain ridges, and generally 'yard', as it is termed, on the side facing the south, where there are abundance of maple and other hard-wood trees upon which to feed, either by browsing on the tender twigs or peeling the bark from the stems of such as are only three or four inches in diameter. Their long, pendulous upper lip is admirably adapted for grasping and pulling down the branches, which are held between the fore legs until all the twigs are eaten. They peel off the bark by placing the hard pad on the roof of the 
mouth against the tree, and scraping upwards with their sharp, gouge-like teeth, completely denuding the tree to the height of seven or eight feet from the surface of the snow. They remain near the same spot as long as any food can be obtained, seldom breaking fresh snow, but keeping to the same tracks as long as possible.

"The antlers begin to sprout in April, and at first appear like two black knobs. They complete their growth in July, when the skin which covers them peels off and leaves them perfectly white; exposure to the sun and air, however, soon renders them brown. When we consider the immense size to which some of them grow in such a short period of time, it seems almost incredible that two such enormous excrescences could be deposited from the circulating system alone; the daily growth is distinctly marked on the velvety covering by a light shade carried around them. The first year the antlers are only about one inch long; the second year, four or five inches, with perhaps the rudiment of a point; the third year about nine inches, when each divides into a fork still round in form; the fourth year they become palmated, with a brow antler and three or four points; the fifth season they have two crown antlers and perhaps five points; the points increasing in size each year, and one or two points being added annually, until the animal arrives at its greatest vigour; after which period they decrease in size and the points are not so fully thrown out. The longest pair I ever met with had eighteen points, (others have seen them with twenty-three points,) they expanded five feet nine inches to the outside of the tips; the breadth of palm, eleven inches without the points; circumference of shaft, clear of the burr, nine inches; weight, seventy pounds! The old and vigorous animals invariably shed them in December: some of four and five years old I have known to carry them as late as March, but this is not often the case.

"The rutting season commences in September; the males then become very furious, chasing away the younger and weaker ones. They run bellowing through the forest, and when two of equal strength meet, have dreadful conflicts, and do not separate until one or both are severely injured. I bought a pair of antlers from a Penobscot Indian, with one of the brow antlers and the adjoining prong broken short off. The parts were at least $1 \frac{1}{2}$ inches in diameter, and nearly as hard as ivory. At that season they are constantly on the move, swimming large lakes and crossing rivers in pursuit of the female.

"The female brings forth in May. The first time she produces one fawn, but ever afterwards two. It is supposed by hunters that these twins are always one a male and the other a female.

"In summer the hair of the Moose is short and glossy-in winter long and 
very coarse, attached to the skin by a very fine pelicle, and rendered warm by a thick coat of short, fine wool. The hair on the face grows upwards from the nose, gradually turning and ending in a thick, bushy tuft under the jaws. The young males have generally a long, pendulous gland, growing from the centre of this tuft, and covered with long hair, sometimes a foot long.

"Their flesh is very coarse, though some people prefer it to any other; it is apt to produce dysentery with persons unaccustomed to use it. The nose or moufle, as it is generally called, if properly cooked is a very delicious morsel. The tongue is also considered a delicacy; the last entrail (called by hunters the bum-gut) is covered with round lumps of suety fat, which they strip off and devour as it comes warm from the animal, without any cooking. Also the marrow warm from the shanks is spread upon bread, and eaten as butter. I must confess that the disgusting luxury was rather too rich to tempt me to partake of it. I have seen some officers of the Guards enjoy it well enough !

"The seasons for hunting the Moose are March and September. In March, when the sun melts the snow on the surface and the nights are frosty, a crust is formed, which greatly impedes the animal's progress, as it has to lift its feet perpendicularly out of the snow or cut the skin from its shanks by coming in contact with the icy surface.

"It would be useless to follow them when the snow is soft, as their great strength enables them to wade through it without any difficulty. If you wish to see them previous to shooting them from their "yard," it is necessary to make your approach to leeward, as their sense of smelling and hearing is very acute: the crack of a breaking twig will start them, and they are seldom seen any more, until fatigue compels them to knock up, and thus ends the chase. Their pace is a long trot. It is necessary to have two or three small curs (the smaller the better), as they can run upon the snow without breaking through the crust; their principal use is to annoy the Moose by barking and snapping at their heels, without taking hold. A large dog that would take hold would be instantly trampled to death. The males generally stop, if pressed, and fight with the dogs ; this enables the hunter to come up unobserved and dispatch them. Sometimes they are killed after a run of an hour, at other times you may run them all day, and have to camp at night without a morsel of provisions or a cloak, as everything is let go the moment the Moose starts, and you are too much fatigued to retrace your steps to procure them. Your only resource is to make a huge fire, and comfort yourself upon the prospect of plenty of Moose-meat next day. As soon as the animal finds he is no longer pursued, he lies down, and the next morning 
he will be too stiff to travel far. Generally, a male, female, and two fawns are found in a 'yard.'

"When obliged to run, the male goes first, breaking the way, the others treading exactly in his tracks, so that you would think only one has passed. Often they run through other 'yards,' when all join together, still going in Indian file. Sometimes, when meeting with an obstacle they cannot overcome, they are obliged to branch off for some distance and again unite; by connecting the different tracks at the place of separation you may judge pretty correctly of their number. I have seen twelve together, and killed seven of them.

A method of hunting this animal is as follows :

"In September, two persons in a bark canoe paddle by moonlight along the shore of the lake imitating the call of the male, which, jealous of the approach of a stranger, answers to the call and rushes down to the combat. The canoe is paddled by the man in the stern with the most deathlike silence, gliding along under the shade of the forest until within short shooting distance, as it is difficult to take a sure aim by moonlight ; the man in the bow generally fires, when if the animal is only wounded, he makes immediately for shore, dashing the water about him into foam; he is tracked by his blood the next day to where he has lain down, and where he is generally found unable to proceed any further. Many are killed in this manner in the neighbourhood of Moose River every season.

Hunters sometimes find out the beaten tracks of the Moose (generally leading to the water), and bend down a sapling and attach to it a strong hempen noose hanging across the path, while the tree is confined by another cord and a sort of trigger. Should the animal's head pass through the dangling snare, he generally makes a struggle which disengages the trigger, and the tree springing upward to its perpendicular, lifts the beast off his legs, and he is strangled !"

Mr. John MArtyn, of Quebec, favoured us with the following notes on the Moose deer: "This animal in the neighbourhood of this city (Quebec) is mostly found in the hard woods during the winter. At this season several associate together and form groups of two, three, or four, and make what is called 'a yard,' by beating down the snow; and whilst in such places they feed on all the branches they can reach, and indeed even strip the trees of their bark, after which they are forced to extend their 'yards,' or remove to some other place, but rather than leave the first, they will even break branches as large as a man's thigh. In skinning off the bark, the animal places its upper lip firmly against it, whether upward, downward or sideways, and with its teeth, which are all on its lower jaw, voL. II. -24 . 
takes a firm hold and tears it away in strips more or less long and broad, according to the nature of the bark of the tree.

It is ascertained by the hunter whether a Moose has been lately or not in its yard, by removing the surface of the snow from around the foot of the trees already barked above, and if they have been barked below the surface of the snow, the animal has left the spot for sometime, and it is not worth while to follow any of its tracks. The contrary, of course, takes place with different observations. At this season the female is generally accompanied by two of her calves, one two years old and generally a bull, the other the calf of the preceding spring.

These animals vary much in their colour, some being grayish brown, and others nearly black. The grayish Moose is generally the largest, often reaching the height of seven or eight feet. The females receive the males in the month of October, and at this period the latter are excessively vicious and dangerous when approached, whilst the females evince the same fierceness at the time of having calves. In some instances during the rutting season, when two males accidentally meet, they fight prodigiously hard, tearing up the earth beneath for yards around, and leaving marks of blood sufficient to prove that their encounter has been of the severest nature.

Their usual mode of defence consists in striking at their enemies with their forefeet; but in fighting with each other the males use both feet and horns, and they have sometimes been killed with marks of old wounds about their head and other parts of the body. As an instance of the force with which the Moose strikes, the following anecdote may be related: a bull-terrier in attempting to seize one by the nose, was struck by the animal with its forefoot, and knocked off to a distance of twenty feet; the dog died next day.

The Moose deer frequently turn against the hunters, even before being shot at or in the least wounded. They walk, trot, and gallop, and can leap a great distance at a single bound; like other species of deer they bend their bodies very low at times, to pass beneath branches of fallen trees, not even half their height from the earth. When pursued, they enter the most tangled thickets, and pass through them as if not feeling the impediments, the brushwood, fallen logs, \&c., opposed to the hunter's progress. The calves when born are about the size of a few days old colt, but are more slender, and look very awkward on account of their apparent disproportionate long and large legs. When caught at three months old, they eat leaves, \&c. ; but how long they are suckled by their dam we have not been able to ascertain.

"During the summer they frequently resort to the shores of rivers, 
creeks or lakes, on the margins of which their tracks are seen, like those of common cattle; they enter the water and immerse their bodies to save themselves from the bites of flies, \&c.

In all probability, where wolves are yet abundant, these are their most dangerous enemies besides man; but at the present time, few of these rapacious animals are to be found in the neighbourhood of Quebec. The Moose deer are frequently killed while in the water. or on the shores of some pond, lake or river; but when their young are with them, they will run and chase the hunter, and it is sometimes difficult for him to escape, unless he is so fortunate as to shoot and bring them down.

"The flesh is considered very good, especially the mouffon, which forms the upper lip, and is very rich, juicy and gelatinous. This is cleaned and dressed in the same manner as 'calves' head.' The hunters salt their meat for winter use. The steaks are as good as beef steaks; but the Moose are not generally fat, although their flesh is juicy and at times tender. The young at the age of twelve months are never tough, and their flesh is preferable to that of the old beasts. The inside of the mouth above, or palate, is extremely hard, and lays in folds, giving this animal the power of gripping ( seizing) the bark or the branches of trees, by which means it tears them off with ease. This pad is placed immediately beneath the extremity of the moufflon, and is about two inches long.

"These animals feed principally on the birch, the moose-wood, the aspen, and various kinds of leaves and grasses; in captivity they eat hay and other dry food, even hard ship-biscuit. The females are called 'cows,' the males 'bulls,' and the young ' calves.' Their droppings resemble those of the deer kind. Although the Moose swim well they are not known to dive, they swim with the head and part of the neck above water, like cattle. When pursued in boats they frequently attempt to upset them, and at times open their mouths and make a loud snorting noise, striking at the same time with their forefeet, and occasionally sink the canoes of the Indians or hunters. Upon one occasion, a young man going fishing, and having his fowling-piece along, on turning a point of a lake, saw a large Moose in the water and fired at it with shot, tickling it severely. The Moose at once made for the canoe; and whilst the alarmed fisherman was attempting to escape, his boat became entangled in the branches of a fallen tree, when he was forced to give up the canoe and get away as he best could; the animal on reaching the boat completely demolished it. Unfortunately, the females are sometimes killed when they are with calf. They do not generally make any noise in the woods, unless when provoked, but in captivity they utter a plaintive sound, much resembling that made by the black bear. 
They never are seen on the ice like the rein-deer; it would seem by the formation of their hoofs that they might walk well on the rocks, or on the ice, but they keep in the woods, and when walking over snow their feet usually sink into it until they reach the earth.

"A Mr. Bell, residing at Three Rivers, has a Moose which has been taught to draw water in a cart or in a sleigh during winter, but there is no possibility of working it during the rutting season. We have never heard of any attempt to ride on the Moose deer. Their horns, which are large, palmated, and heavy, are dropped in the months of December and January, begin to show again in the latter part of March, and in two months or thereabouts attain their full size. When covered over with 'velvet,' as it is called, they are very curious. A pair of good Moose horns sells at the high price of twenty dollars! The velvet is scraped off against trees and bushes in the manner employed by our Virginian deer. Horns have been measured when reversed and standing on the ground four feet seven inches, and ordinary pairs often measure five feet and upwards.

"It is said that the Moose can smell at a very great distance, and that the moment they scent a man or other enemy they make off and are not easily overtaken. On the first glimpse of man, if they are lying down they rise to their feet and are off at once, and often before they are observed by the hunter. When closely pursued, they turn and make a dash at the enemy, scarcely giving him time to escape, and the hunter's best plan in such cases is to keep cool and shoot the animal as it rushes towards him, or if unprepared, he had best ascend a tree with all convenient dispatch. Sometimes the hunter is obliged to save himself by dodging around a tree, or by throwing down some part of his dress, upon which the Moose expends his fury, trampling on it until torn to tatters.

"Moose-hunting is followed by white or red skinned hunters in the same manner. He, however, who has been born in the woods, possesses many advantages over the 'civilized' man. The white hunters generally provide themselves, previous to their starting, amply with provisions and ammunition to last them about three weeks, and sometimes go in a sleigh. The guns used are mostly single-barrelled, of ordinary size, but suited for shooting balls as well as shot,-rifles are rarely used in Canada. After leaving the settlements, the first day's journey takes them ten or twelve miles, when they select a proper place in a snowy district, as near a stream as possible.

"If the weather is fine, they cut down trees and make a camp, some of the party provide water, and others light the fires and clear off the snow for yards around, whilst evergreen trees are stripped of their branches to 
make up a floor and covering for them in their temporary shelter. The hunters having made all snug, cook their meat and eat it before a fire that illuminates the woods around, and causes the party to appear like a set of goblins through the darkness of night. On many such occasions the bedding is singed, and per chance a whisker! The feet may be partially roasted, whilst the shoulders, the hands, and probably the nose, are suffering greatly from the severity of the weather, for the thermometer may be occasionally thirty degrees below zero! The march to this spot is frequently made on snow-shoes, which are taken off, however, whilst the party are forming the encampment, clearing away the snow, and making a path to the water, which being covered with snow and ice, requires to be got at by means of shovels and axes. Before daylight, the kettles are put on the fires, tea and coffee are made, breakfast swallowed in a few moments, and the party on foot, ready to march toward the hunting-ground. On the way, every one anxiously looks out for tracks of the game, and whether hares or grouse come in the way they are shot and hung up on the trees; but if game of any kind has been thus hung up by others, whether Indians or white hunters, the party leaves it sacredly untouched-for this is the etiquette of the chase throughout this portion of country. When they at last reach the ground, the party divide, and seek for the Moose in different directions. It is agreed that no one shall shoot after separating from the rest, unless it be at the proper game, and also that in case of meeting with Moose, or with fresh signs, they are to return, and make ready to proceed to the spot together next day. Sometimes, however, this rule is broken through by some one whose anxiety (excitement) at sight of a Moose makes him forget himself and his promise. As soon as a 'yard' has been discovered, all hands sally forth, and the hunt is looked upon as fairly begun. If on approaching the 'yard,' their dogs, which are generally mongrels of all descriptions, start a Moose, the hunters, guided by their barking and the tracks of the pack and the Moose through the snow, follow with all possible celerity. The dogs frequently take hold of the Moose by the hind legs, the animal turns, and stands at bay, and the hunters thus have an opportunity to come up with the chase.

"On approaching, when at the proper distance (about sixty to eighty yards) the nearest man takes a decided aim, as nearly as possible under the forearm and through the neck, and fires, or, if fronting the beast, in the centre of the breast.

"If wounded only, the second hunter fires also, and perhaps the third, and the animal succumbs at last, though it sometimes manages to run, stumble, and scramble, for miles. After skinning the Moose, 
the heart and liver, and the marrow-bones, are taken out, and a good large piece of the flesh is taken to 'camp,' and is speedily well cooked and placed smoking hot before the hungry hunters. After killing all the Moose of a 'yard' or that they can find near their camp, the party pack up their material, break up the camp, and return home.

It not unfrequently happens, that a wounded Moose, or even one that has not been wounded, will turn upon the hunter, who then has to run for his life, and many instances of such incidents are related, including some hair-breadth escapes. One of these I will relate: Two Indians being on a hunt and having met with the game, one of them shot, and missed; the Moose turned upon him, and he fled as fast as he could, but when about to reach a large tree, from behind which he could defy his opponent, his snow shoes hooked in some obstacle and threw him down. The Moose set upon him furiously and began trampling on him, but the Indian drew out a knife, and succeeded in cutting the sinews of the forelegs of the animal, and finally stabbed him so repeatedly in the belly that he fell dead, but unluckily fell on the prostrate hunter, who would have been unable to extricate himself, had not his companion come to his assistance. The poor man, however, had been so much injured that he never recovered entirely, and died about two years afterwards.

During some seasons the snows are so deep, and at times so soft, that the Moose cannot go over the snow, but have to make their way through it, giving a great advantage to the hunters, who, on broad snow-shoes can stand or run on the surface without much difficulty. On one occasion of this nature a Moose was seen, and at once followed. The poor animal was compelled to plough the snow, as it were, and the hunters came up to it with ease, and actually placed their hands on its back. They then endeavoured to drive it towards their camp and secure it alive. The Moose, however, would not go in the proper direction, and they finally threw it down, and attempted to fasten its legs together; but as they had no ropes, and could not procure any better substitute for them than withes, the beast got away, and after a long chase they, being very much fatigued, shot it dead. When the snow is thus soft, the Moose deer has been known to evade the hunters by pushing ahead through tangled thickets, more especially hackmetack and briary places which no man can go through for any length of time without extreme labour. The Indians, however, will follow the Moose in such cases day and night, provided the moon is shining, until the animal is so fatigued that it can be overtaken and killed with ease. Instances have been known where as many as five have been killed in one day by two Indians. The Moose is not unfrequently caught in the following manner: A rope is passed over 
a horizontal branch of a tree, with a large noose and slip-knot at one end, whilst a heavy $\log$ is attached to the other, hanging across the limb or branch, and touching the ground. The Moose, as it walks along, passes its head through the noose, and the farther it advances, the tighter it finds itself fastened, and whilst it plunges terrified onwards, the log is raised from the ground until it reaches the branch, when it sticks, so that no matter in what manner the Moose moves, the log keeps a continued strain, rising and falling, but not giving the animal the least chance to escape, and at last the poor creature dies miserably. They are also 'pitted' at times, but their legs are so long, that this method of securing them seldom succeeds, as they generally manage to get out."

The Moose is well known to travellers who have crossed the Rocky Mountains, where this animal is principally called by the French name, "L'Orinal."

Whilst at Quebec, in 1842, we procured the head and neck of a very large male, (handsomely mounted); which was shot in the state of Maine, where the Moose is still frequently found.

Moose deer are abundant in Labrador, and even near the coast their tracks, or rather paths, may be seen, as distinctly marked as the cow-paths about a large stock-farm. In this sterile country, where the trees are so dwarfish that they only deserve the name of shrubs, and where innumerable barren hills arise, with cold clear-water ponds between, the Moose feeds luxuriously on the scanty herbage and the rank summer grasses that are found on their sides; but in winter the scene is awfully desolate, after the snows have fallen to a great depth; the whistling winds, unimpeded by trees or forests, sweep over the country, carrying with them the light snow from the tops and windward sides of the hills in icy clouds, and soon forming tremendous drifts in the valleys. No man can face the stormdriven snows of this bleak, cold country; the congealed particles are almost solid, and so sharp and fine that they strike upon the face or hands like small shot; the tops of the hills are left quite bare and the straggling Moose or rein deer seek a precarious supply of mosses along their sides. At this season the Moose sometimes crosses the Gulf of St. Lawrence, on the ice to Newfoundland, or follows the coast towards the shore opposite Nova Scotia, and there passes the Gulf and wanders into more woody and favoured regions for the winter.

The following is from our friend S. W. Rodmax, Esq., of Boston, an excellent sportsman, and a lover of nature, to whom we are indebted for many kindnesses.

"Our party was returning from lake Miramichi, about the middle of July, by the marshy brook, which connects it with the Miramichi river. The canoe men were poling slowly and silently, in order not to disturb the numerous ducks which breed in those uninhabited solitudes, as we were anxious to vary our constant fish dict ; salmon either boiled or "skinned" being set before us morning, noon and 
night. We had not fired a gun to disturb the silence. My own and my brother's canoes were close together, when I saw an animal suddenly spring on to its feet from the long marshy grass about forty yards in advance of us. I said quickly "Cariboo," "Cariboo," "stoop low ;" which we all did and continued moving on. It was about the size of a yearling heifer, but taller, of a bright, light, red colour, with long ears pricked forward, and a large soft eye; and stuod perfectly still, looking at us. We had gone perhaps ten yards, when there appeared from the long grass by its side, first the ears, then the huge head and muffle of an old cow Moose, the first one being as I now knew her calf, of perhaps four or five months old. She gradually rose to her knees, then sat upon her haunches, and at last sprang to her feet, her eyes all the time intently fixed upon us. The calf in the meanwhile had moved slowly off. At this moment we both fired without any apparent effect, the shot being too light to penetrate the thick hide. She turned instantly, showing a large and apparently well filled udder, struck into the tremendous trot, for which the Moose is so celebrated, crossed the deep brook almost at a stride, then the narrow strip of meadow, and disappeared, crashing through the alders which intervened between the meadow and the dark evergreen forests beyond.

Our oldest woodsman, Porter, assured us that she was one of the largest of her kind, and that it was rare good fortune to approach so near to this noblest denizen of our northern forests. We were much gratified, but our regret as sportsmen was still greater, at not having been prepared to take advantage of such an opportunity as will probably never again occur to either of us. We constantly both before and afterwards saw the tracks of cariboo and Moose about our camps."

\section{GEOGRAPHICAL DISTRIBUTION.}

Capt. Franklin, in his last expedition, states that several Moose were seen at the mouth of Mackenzie River, on the shores of the Arctic Sea, in latitude $69^{\circ}$. Farther to the eastward towards the Copper-mine River, we are informed by Richardson, they are not found in a higher latitude than $65^{\circ}$. Mackenzie saw them high up on the eastern declivity of the Rocky Mountains, near the sources of the Elk River; Lewis and CLARK saw them at the mouth of the Oregon. To the east they abound in Labrador, Nova Scotia, New-Brunswick, and Lower Canada. In the United States they are found in very diminished numbers in the unsettled portions of Maine and at long intervals in New-Hampshire and Vermont. In the state of New-York, according to the observations, made by Dr. Deкау, (Nat. Hist. N. Y., p. 117), which we believe strictly correct, they yet exist in Herkimer, Hamilton, Franklin, Lewis and Warren counties, and their southern limit along the Atlantic coast is $43^{\circ} 30^{\prime}$.

\section{GENERAL REMARKS.}

We have considerable doubts whether our Moose deer is identical with the Scandinavian elk (Cervus alces, of authors), and have therefore not quoted any of the synonymes of the latter, but having possessed no favourable opportunities of deciding this point, we have not ventured on the adoption of any of the specific names which have from time to time been proposed for the American Moose. 


\section{$2 \mathrm{BHL}$ Biodiversity Heritage Library}

Audubon, John James and Bachman, John. 1851. "Cervus alces, Moose Deer [PI. LXXVI, old male and young]." The quadrupeds of North America 2, 179-192. https://doi.org/10.5962/p.322388.

View This Item Online: https://www.biodiversitylibrary.org/item/108514

DOI: https://doi.org/10.5962/p.322388

Permalink: https://www.biodiversitylibrary.org/partpdf/322388

\section{Holding Institution}

Duke University Libraries (archive.org)

\section{Sponsored by}

Duke University Libraries

\section{Copyright \& Reuse}

Copyright Status: Not provided. Contact Holding Institution to verify copyright status.

This document was created from content at the Biodiversity Heritage Library, the world's largest open access digital library for biodiversity literature and archives. Visit BHL at https://www.biodiversitylibrary.org. 